\title{
THE EFFECT OF THE LEVEL OF MILK YIELD ON THE REPRODUCTION TRAITS IN BLACK AND WHITE COWS
}

\author{
R. Djedović ${ }^{1}$, V. Bogdanović ${ }^{1}$, G. Trifunović ${ }^{1}$, M. D. Petrović ${ }^{2}$, M. M. \\ Petrović $^{3}$, D. Stanojević ${ }^{1}$ \\ ${ }^{1}$ Department of ZOO Techniques, University of Belgrade, Faculty of Agriculture, Nemanjina 6, \\ Zemun, Republic of Serbia \\ ${ }_{2}^{2}$ Faculty of Agronomy, Cara Dušana 34, 32000, Čačak, Republic of Serbia, University of Kragujevac \\ ${ }^{3}$ Institute for Animal Husbandry, Autoput 16, 11080, Belgrade-Zemun, Republic of Serbia \\ Corresponding author: genrad@agrif.bg.ac.rs \\ Original scientific paper
}

Abstract: In this study a relationship between the milk yield and following reproduction traits: number of inseminations per conception [AIS], service period [SP], age at calving $[\mathrm{AC}]$, calving interval $[\mathrm{CI}]$ and birth weight $[\mathrm{BW}]$ is studied. The research involved dairy cows of European type of Black and White cattle which are being intensively improved by the genes of Holstein - Friesian breed. Mean values of general average for number of inseminations per conception, service period, age at calving, calving interval and birth weight are: 2.00; 98.78; $1088.08 ; 376.70$ and 36.40 , respectively. In general, the estimated phenotypic correlations $\left(\mathrm{r}_{\mathrm{p}}\right)$ between the milk yield over standard lactations and fertility traits were positive and unfavorable, and ranged from 0.24 for the relationship between milk yield and birth weight to 0.70 for relationship between milk yield and age at calving. and White cattle

Key words: level of milk yield, reproduction traits, phenotypic correlation, Black

\section{Introduction}

In intensive milk production over a longer period of years the problem regarding the reproduction and diminished fertility in cows has been observed. For a practical raising of cattle it is important to study the influence of the level of milk yield on bovine fertility since between reproduction and lactation there is a close physiological correlation. By studying the influence of milk yield on bovine fertility different results have been obtained. The authors of a great number of papers have reported that high-yielding dairy cows exhibit lower fertility and greater health disorders in relation to low producing dairy cows (Rauw et al., 
1998; Pryce et al.,1999, 2004; Sandoe et al., 1999; Lucy, 2001; Rokstrom et al.,2001; Windig et al., 2005; Tekerli and Koçak, 2009; Scholz et al., 2010; Sun et al., 2010).

These problems are present especially on those farms that raise larger populations of high-producing Holstein and Black and White dairy cows (CastilloJuarez et al., 2000; et al Lucy, 2001; Sørensen and Ruiz, 2007) who are also expected, besides producing high milk yield in lactation, to produce a healthy and vital calf once a year. If a disorder occurs in bovine reproductive cycle, besides its direct consequences on realized milk production, the realization of normal herd maintenance is also rendered impossible.

As a confirmation of a very complicated processes in bovine reproduction serves a record which shows that only about $40-50 \%$ cows become pregnant at first insemination (Royal et al,. 2000), thus the fertility in the populations of American Holstein cows is decreasing at the rate of $0.5-1.0 \%$ units annually (Bousquet et al., 2004).

Taking into account that economic importance of reproductive traits of dairy cattle is essential it is necessary to understand the factors which influence bovine fertility, and they are all divided into genetic and paragenetic (environmental factors). The success of improving fertility by genetic means is limited by low heritability performance although it does not mean that genes do not affect this trait but more that the value of additive genetic variation is small (Djedovic et al., 2002). The fertility in cows is considerably more influenced by environmental factors because the majority of variations of reproductive parameters is under their influence. When single factors are analyzed it is observed that their influence on bovine fertility is of a different degree and also that a complex influence is possible. By the entire understanding of more different effects on reproductive traits in cows the fertility of dairy herds can be improved.

The research of some authors (Rokstrom et al,. 2001; Windig et al., 2006) showed that there are unfavourable correlations between milk yield and fertility traits. They have confirmed low to mean values of coefficients of phenotypic and genetic correlations between milk yield and fertility traits (Pryce et al., 1999; Oltenacu and Algers, 2005; Jagusiak, 2006).

Antagonistic relationship between these two groups of traits confirmed in literature shows the necessity that the fertility traits should be included in overall selection index.

The aim of this paper was to establish the effect of different levels of milk yield on the most important reproduction traits as well as to give the grounds for the estimation of genetic variability and relationship between studied traits depending on the level of milk yield. 


\section{Material and methods}

\section{Data}

The research on the effect of different level of milk yield as a paragenetic factor on the reproduction traits was conducted on a farm of high-yielding Black and White cattle. The farm is situated in the region characterized by intensive vegetable production with capacity of about 500 milking animals. The cows belong to European type of Black and White cattle whose genotype is being improved intensively by introducing genes of Holstein-Friesian breed (HF). The study included 730 standard lactations in a whole.

The criteria for involving the animals into trial were as follows:

- $\quad$ to be involved in milk production during the trial period,

- $\quad$ to have records on origin for three preceding generations,

- $\quad$ to have concluded the first, second and third lactation,

- $\quad$ to have lactations not shorter than 210 days.

For study purposes, that is, for establishing the relationship between the level of milk yield and reproduction traits all the cows were assigned per lactations into three groups with different share of Holstein genes. The groups were formed based on the distribution of the frequency of genotypes regarded per lactations. All the cows per lactation groups were classified into three classes depending on the level of milk production (I, II and III). The milk yield classes were formed on the basis of distribution of frequency of milk yield regarded per lactations (Table 1).

An average milk yield for the first (I) level was 5786, the second (II) 6976 and the third (III) $8263 \mathrm{~kg}$.

Table 1. Distribution of records per lactations, share of HF genes and milk yield levels

\begin{tabular}{|l|c|c|c|c|c|c|}
\hline \multirow{2}{*}{ Lactation } & \multicolumn{3}{|c|}{ Share of HF genes, \% } & \multicolumn{3}{c|}{$\mathrm{n}$} \\
\cline { 2 - 7 } & I & II & III & I & II & III \\
\hline I & $0-33$ & $34-48$ & $49-100$ & 87 & 118 & 104 \\
\hline II & $0-33$ & $34-48$ & $49-100$ & 75 & 100 & 61 \\
\hline III & $0-33$ & $34-48$ & $49-100$ & 54 & 85 & 46 \\
\hline \multirow{3}{*}{ Lactation } & \multicolumn{7}{|c|}{ Level of milk yield, $\mathrm{kg}$} & \multicolumn{3}{c|}{} \\
\cline { 2 - 7 } & I & II & III & I & II & III \\
\hline I & $<4600$ & $4600-5500$ & $>5500$ & 91 & 141 & 77 \\
\hline III & $<5600$ & $5500-6200$ & $>6200$ & 73 & 89 & 74 \\
\hline I-III & $<5800$ & $5800-6700$ & $>6700$ & 56 & 72 & 57 \\
\hline
\end{tabular}

Model

Phenotypic variability and correlation of studied traits were established by the Least Square Method (Harvey, 1990) that is, by the use of following fixed model: 
$\mathrm{Y}_{\mathrm{ijkl}}=\mu+\mathrm{L}_{\mathrm{i}}+\mathrm{N}_{\mathrm{j}}+\mathrm{LN}_{\mathrm{ij}}+\mathrm{G}_{\mathrm{k}}+\mathrm{S}_{1}+\mathrm{LS}_{\mathrm{il}}+\mathrm{b}_{1}\left(\mathrm{x}_{1}-\bar{x}_{1}\right)+\mathrm{b}_{2}\left(\mathrm{x}_{2^{-}} \bar{x}_{2}\right)+\mathrm{e}_{\mathrm{ijkl}}$

where:

$\mathrm{Y}_{\mathrm{ijk} k \mathrm{mo}}$ - is the manifestation of the trait of o- individual, i- lactation, $\mathrm{j}$ - milk yield level , k- year of calving, 1 - calving season,

$\mu-$ general average of population for given trait,

$\mathrm{L}_{\mathrm{i}}$ - fixed effect of $\mathrm{i}$ - lactation $(\mathrm{i}=1, . .3)$,

$\mathrm{N}_{\mathrm{j}}$ - fixed effect of $\mathrm{j}$ - milk yield level $(\mathrm{j}=1, . .3)$,

$\mathrm{LN}_{\mathrm{ij}}$ - fixed effect of $\mathrm{i}$ - lactation and $\mathrm{j}$ - milk yield level $(\mathrm{ij}=1, . .9)$,

$\mathrm{G}_{\mathrm{k}}$ - fixed effect of $\mathrm{k}$ - year at calving $(\mathrm{k}=1, . .5)$,

$\mathrm{S}_{1}$ - fixed effect of 1 - calving season $(1=1, . .4)$,

$\mathrm{LS}_{\mathrm{il}}$ - fixed effect of interaction of $\mathrm{i}$ - lactation and fixed effect of $1-$ calving season $(i 1=1 \ldots 12)$,

$b_{1}$ - linear regression effect of the share of Holstein-Friesian (HF) bovine genes,

$\mathrm{b}_{2}$ - partial regression effects of the share of Holstein-Friesian (HF) genes per milk yield levels,

$\mathrm{e}_{\mathrm{ijkl}}-$ random error with characteristics $\mathrm{N}\left(0, \sigma^{2}\right)$.

\section{Results and Discussion}

The mean values as well as the deviations and deviation errors from the mean value for studied reproduction traits depending on the level (classes) of milk yield are shown in Table 2 .

Table 2. Mean values (LSM), mean deviations (q) and standard errors of mean deviations $\left(\mathrm{S}_{\mathbf{q}}\right)$ for reproduction traits depending on milk yield level ${ }^{1}$

\begin{tabular}{|l|c|c|c|c|c|c|c|}
\hline \multirow{2}{*}{$\begin{array}{l}\text { Level of } \\
\text { milk yield }\end{array}$} & \multicolumn{6}{|c|}{ Reproduction traits } \\
\cline { 4 - 8 } & LSM & \multirow{2}{*}{730} & 2.00 & 98,78 & 1088,08 & 376,70 & 36,40 \\
\cline { 4 - 8 } & $\mathrm{Se}$ & & 0,07 & 2,71 & 0,92 & 2,68 & 0,15 \\
\hline \multirow{2}{*}{ I Low } & $\mathrm{q}$ & \multirow{2}{*}{220} & $-0,32$ & $-14,52$ & $-1,56$ & $-14,23$ & $-0,28$ \\
\cline { 4 - 8 } & $\mathrm{S}_{\mathrm{q}}$ & & 0,08 & 2,78 & 0,94 & 2,76 & 0,15 \\
\hline II & $\mathrm{q}$ & \multirow{2}{*}{302} & $-0,12$ & $-7,39$ & 0,27 & $-7,32$ & 0,09 \\
\cline { 4 - 8 } Medium & $\mathrm{S}_{\mathrm{q}}$ & & 0,07 & 2,54 & 0,86 & 2,52 & 0,14 \\
\hline \multirow{2}{*}{ III High } & $\mathrm{q}$ & \multirow{2}{*}{208} & 0,44 & 21,91 & 1,29 & 21,55 & 0,19 \\
\cline { 4 - 8 } & $\mathrm{S}_{\mathrm{q}}$ & & 0,08 & 2,79 & 0,95 & 2,77 & 0,15 \\
\hline $\mathrm{F}_{\exp }$ & & & $13,80^{* *}$ & $36,90^{* *}$ & $2,73^{\text {N.S }}$. & $36,18^{* *}$ & $2,56^{\text {N.S. }}$ \\
\hline
\end{tabular}

${ }^{1} \mathrm{LSM}=$ Least squares means, $\mathrm{SE}=$ Standard error; $\mathrm{AIS}=$ number of inseminations per conception; $\mathrm{SP}=$ service period (days); $\mathrm{AC}=$ age at calving (days); $\mathrm{CI}=$ calving interval (days); $\mathrm{BW}=$ birth weight $(\mathrm{kg})$

$\mathrm{NS}-(\mathrm{P}>0,05) *-(\mathrm{P}<0,05) * *-(\mathrm{P}<0,01)$ 
Mean value of the number of inseminations per conception for all animals was $2.00 \pm 0.07$. Deviations from the mean value ranged in the interval from -0.32 (I class) to 0.44 (III class). By the variance analysis a statistically highly significant differences $(\mathrm{P}<0.01)$ were established. Service period for all animals lasted $98 \pm 2.71$ days on average, varying from 84.25 (I class) to 120.69 (III class), with the range of constant deviations from -14.52 to 21.91 days. Regarded from a statistical point of view the variations for the longevity of service period were highly significant $(\mathrm{P}<0.01)$. The age at calving for all studied individuals was $1088.08 \pm 0.92$ days. By the proceedings of the variance analysis a statistically significant differences $(\mathrm{P}>0,05)$ were not confirmed. The average value for calving interval was $376.70 \pm 2.68$ days. Variations were in the interval of 362.50 (I class) to 398.30 days (III class) and deviations from the mean value from -14.23 to 21.55 days (I and III class). For this studied trait a highly significant differences were established $(\mathrm{P}<0.01)$, regarded per different classes of milk yield. The mean value of birth weight was $36.40 \pm 0.15 \mathrm{~kg}$. The constants deviations from the mean value regarded per sequence of classes were: $-0.28 ; 0.09$ and $0.19 \mathrm{~kg}$, respectively. A statistical significance of the milk yield on the birth weight was not manifested $(\mathrm{P}>0.05)$.

Determined phenotypic correlations $\left(r_{p}\right)$ between the milk yield and reproduction traits were positive in general, and had low and mean values as regards strength, except for the correlation between the milk yield and age at calving (Table 3 ).

Table 3. Phenotypic correlations for reproduction traits depending on milk yield level ${ }^{1}$

\begin{tabular}{|c|c|c|c|c|c|c|}
\hline $\begin{array}{c}\text { Level of } \\
\text { milk } \\
\text { yield }\end{array}$ & Trait & AIS & SP & AC & CI & BW \\
\hline $\begin{array}{c}\text { I } \\
\text { Low }\end{array}$ & MILK & $0,355^{* *} \pm 0,033$ & $0,382^{* *} \pm 0,062$ & $0,701^{* *} \pm 0,048$ & $0,379^{* *} \pm 0,062$ & $0,399^{* *} \pm 0,062$ \\
\hline $\begin{array}{c}\text { II } \\
\text { Medium }\end{array}$ & MILK & $0,293^{* *} \pm 0,055$ & $0,396^{* *} \pm 0,053$ & $0,685^{* *} \pm 0,042$ & $0,405^{* *} \pm 0,052$ & $0,455^{* *} \pm 0,051$ \\
\hline $\begin{array}{c}\text { III } \\
\text { High }\end{array}$ & MILK & $0,386^{* *} \pm 0,064$ & $0,461^{* *} \pm 0,061$ & $0,484^{* *} \pm 0,060$ & $0,478^{* *} \pm 0,061$ & $0,238^{* *} \pm 0,067$ \\
\hline
\end{tabular}

${ }^{\mathrm{I}} \mathrm{MILK}=305-\mathrm{d}$ milk yield in $\mathrm{kg}$; AIS= number of inseminations per conception; $\mathrm{SP}=$ service period (days);

$\mathrm{AC}=$ age at calving (days); $\mathrm{CI}=$ calving interval (days); $\mathrm{BW}=$ birth weight $(\mathrm{kg})$

$\mathrm{NS}-(\mathrm{P}>0,05) *-(\mathrm{P}<0,05) * *-(\mathrm{P}<0,01)$

Phenotypic correlation between different classes of milk yield and number of inseminations per conception was poor and positive but highly significant. Correlation coefficients were for the first level $r_{p}=0.35$, the second $r_{p}=0.29$ and third $r_{p}=0.39$. By bringing into relationship the level of milk production and service period, a poor and positive correlation was established for I and II class of milk yield, while for the third a mean and positive correlation was confirmed. In all 
three classes a highly significant correlation was confirmed. The correlation coefficients were $r_{p}=0.38 ; r_{p}=0.39$ and $r_{p}=0.46$ (I, II and III level).

In animals with low milk production (I level of milk yield) a poor, positive and highly significant correlation between the milk yield in standard lactation and calving interval was confirmed. On the contrary, both in cows with mean and high milk yield (II and III class) a mean, positive and highly significant correlation was confirmed. The phenotypic correlation coefficients were for the first class $r_{p}=0.38$; second $r_{p}=0.41$ and third $r_{p}=0.48$.

In relation to previously mentioned traits, phenotypic correlation between the milk yield and the age at calving was moderately strong and positive whilst per levels of milk yield it was $r_{p}=0.70$ (I level); $r_{p}=0.69$ (II level) and $r_{p}=0.48$ (III level).

For I and II level of milk yield a phenotypic correlation between the milk yield and birth weight was mean, positive and highly significant. In the third level of milk yield a weak but also positive and highly significant correlation was observed.

By increasing the milk yield a number of inseminations per successful conception increased as well. Likewise the previous trait a symmetrical increase of prolonged service period depending on the increase of milk yield was also established. In the trait regarding the age of cow at calving a high variability was not confirmed, contrary to previous traits. By increasing the milk yield a trend of increasing the duration of calving interval was manifested. Deviations in birth weight from the average value are rather low, so that the observed variations occurred most probably under the effect of some factors not studied herein.

By analysing the established values of reproductive traits it is observed that the effect of the level of milk yield on greater number of the same traits was significant $(\mathrm{P}<0.05)$, ie., highly significant $(\mathrm{P}<0.01)$. Only in two traits (the age at calving and birth weight) a statistical significance was not confirmed $(\mathrm{P}>0.05)$.

The results regarding the research on the effect of milk yield on fertility in dairy cows in different authors vary considerably. The majority of authors report that high-yielding dairy cows exhibit poorer fertility than the animals with lower milk yield (Dematawewa and Berger, 1998; Oltenacu and Algers, 2005; Windig et al., 2005). In these studies the cows which manifested higher milk yield had longer calving interval and therefore a longer service period.

The results in conformity with our results regarding phenotypic variabilities of the number of inseminations per conception, interval between two calvings and age at insemination were obtained also by Stevenson (1999) and Jagusiak (2006). Lower phenotypic values for studied fertility traits in the populations of Black and White cattle reported Atil (2000); Ojango and Pollott (2001); Amani et al. (2007); Vacek et al. (2007) and M'hamdi et al. (2010).

The values for the majority of phenotypic correlations between the milk yield and reproductive traits obtained in this study were around 0.3 (Table 3). 
Estimated phenotypic correlations are unfavourable in general since high-yielding cows display weaker reproductive efficiency.

The greatest number of estimated values of phenotypic correlations between the milk yield and reproductive traits published in literature are on the low and mean level. Price et al. (1999) estimate that unfavourable correlation between the milk yield and calving interval in the populations of dairy cattle was $(0.28 \pm$ 0.06). Hansen et al. (1983) estimated that correlation between the milk yield and number of inseminations per conception was 0.37 .

Number of service periods is the most important part of the calving interval, because variation in gestation length, which represents the second part of the calving interval, is very low (Jagusiak, 2006). Therefore, estimates of the phenotypic correlations between calving interval and milk yield traits are usually similar to those between service period and yield traits.

Thus, Veerkamp et al. (2001) report that estimated correlations between the milk yield and reproductive traits were low and that the values for calving interval were 0.19 ; for service period 0.20 ; and for days to first service 0.15 .

Similarly to our study Marti and Funk (1994) studied the correlation between the milk yield at different levels and reproduction traits and concluded that the highestproducing cows had the longest service period.

Contrary to all previously cited authors Raheja et al. (1989) and Pantelić et al. (2008) established the lowest coefficients of phenotypic correlations between the milk yield and reproductive traits.

\section{Conclusion}

The unfavourable phenotypic correlations obtained between the milk yield and fertility traits in this study as well as the results of cited authors show that the choice of cows based only on the production of milk, over a longer time period, may lead to diminishing of the bovine fertility. Therefore, when estimating the bovine breeding value the values of phenotypic and genetic correlations between the traits of milk yield and fertility should be included in an entire selection index.

\section{Uticaj nivoa mlečnosti na osobine plodnosti krava crno bele rase}

R. Đedović, V. Bogdanović, G. Trifunović, M. Petrović, M. M. Petrović, D. Stanojević

\section{Rezime}

U radu je ispitivan odnos između prinosa mleka i sledećih osobina plodnosti: indeks osemenjavanja [IO], servis period [SP], uzrast pri teljenju [UT], 
međutelidbeni interval $[\mathrm{MI}]$ i masa teladi pri rođenju [MTR]. Ispitivanja su se odnosila na mlečne krave evropskog tipa crno-belih goveda koje se intenzivno oplemenjuju genima holštajn-frizijske rase. Za analizu je korišćen Metod najmanjih kvadrata - LSMLMW (HARVEY, 1990), fiksni model.

Srednje vrednosti opšteg proseka za indeks osemenjavanja, servis period, uzrast pri teljenju, međutelidbeni interval i masu teladi pri rođenju su: 2,00; 98,78; 1088,$08 ; 376,70$ i 36,40, respektivno.

Procenjene fenotipske korelacije $\left(r_{p}\right)$ između prinosa mleka i osobina plodnosti generalno su bile pozitivne i nepovoljne, i imale su vrednosti od 0,24 za odnos između prinosa mleka i masu teladi pri rođenju do 0,70 za odnos između prinosa mleka i uzrasta pri teljenju.

\section{References}

AMANI Z., GADER A., KHAIR M., LUTFI A., PETERS K. (2007): Milk yield and reproductive performance of Friesian cows under Sudan tropical conditions. Arch Tierz 50, 155-164.

ATIL H. (2000): Genetic relationship between days open and days dry with milk yield in a herd of Holstein Friesian cattle. Arch Tierz 43, 583-590.

BOUSQUET D., BOUCHARD E., DUTREMBLAY D. (2004): Decreasing fertility in dairy cows: Myth or reality? Proc. $23^{\text {rd }}$ World Buiatrics Congress, Quebec, Canada, 6.

CASTILLO-JUAREZ H., OLTENACU P.A., BLAKE R.W., MCCULLOCH C.E., CIENFUEGOS-RIVAS E.G. (2000): Effect of herd environment on the genetic and phenotypic relationships among milk yield, conception rate, and somatic cell score in Holstein cattle. J Dairy Sci 83, 807-814.

DEMATAWEWA C.M., BERGER P.J. ( 1998): Genetic and phenotypic parameters for 305-day yield, fertility, and survival in Holsteins. J Dairy Sci 81, 2700-2709.

DJEDOVIĆ R., LATINOVIĆ D., STOJIĆ P., BOGDANOVIĆ V., TRIFUNOVIĆ G. (2002): Heritability of milk traits in cattle depending on the level of production. Biotechnology in animal husbandry 18, 17-22.

HANSEN L.B., FREEMAN A.E., BERGER P.J .(1983): Yield and fertility relationships in dairy cattle. J Dairy Sci 66, 293-305.

HARVEY, WR (1990): Least-Squares and Maximum Likelihood Computer Program. 
JAGUSIAK W. (2006): Fertility measures in Polish Black-and-White cattle. 3. Phenotypic and genetic correlations between fertility measures and milk production traits. J Anim Feed Sci 15, 371-380.

LUCY M.C. (2001): Reproductive loss in high-producing dairy cattle: Where will it end? J Dairy Sci 84, 1277-1293.

MARTI C.F,. FUNK D.A. (1994): Relationship between production and days open at different levels of herd production. J Dairy Sci 77, 1682-1690.

M'HAMDI N., ALOULOU R., BRAR S. K., BOUALLEGUE M., M. BEN HAMOUDA M. (2010): Phenotypic and genetic parameters of reproductive traits in tunisian holstein cows. Biotechnology in Animal Husbandry 26 (56), 297-307.

OJANGO J.M., POLLOTT G.E. (2001): Genetics of milk yield and fertility traits in Holstein-Friesian cattle on large-scale Kenyan farms. J Anim Sci 79, 1742-1750.

OLTENACU P.A., ALGERS B. (2005): Selection for increased production and the welfare of dairy cows. Ambio 34, 311-315.

PANTELIĆ V., PETROVIĆ M.M., ALEKSIĆ S., SRETENOVIĆ LJ., OSTOJIĆANDRIĆ, NOVAKOVIĆ Ž. (2008): Investigation of the genetic correlation between milk and fertility traits of first calving cows of simmental breed. Biotechnology in Animal Husbandry 24 (5-6), 1-8.

PRYCE J.E., NIELSEN B.L., VEERKAMP R.F., SIMM G. (1999): Genotype and feeding system effects and interactions for health and fertility traits in dairy cattle. Livest Prod Sci 57, 193-201.

PRYCE J.E., ROYAL M.D., GARNSWORTHY P.C., MAO I.L. (2004): Fertility in the high-producing dairy cow. Livest Prod Sci 86, 125-135.

RAHEJA K., BURNSIDE E., SCHAEFFER L. (1989): Relationships Between Fertility and Production in Holstein Dairy Cattle in Different Lactations. J Dairy Sci 72, 2670-2678.

RAUW W.M., KANIS E., NOORDHUIZEN-STASSEN E.N., GROMMERS F.J. (1998): Undesirable side effects of selection for high production efficiency in farm animals. Livest Prod Sci 56,15-33.

ROXSTROM A., STRANDBERG E., BERGLUND B., EMANUELSON U., PHILIPSSON J. (2001): Genetic and environmental correlations among female fertility traits and milk production in different parities of Swedish red and white dairy cattle. Acta Agric Scand 51,7-14.

ROYAL M.D., DARWASH A.O., FLINT A.P.F., WEBB R., WOOLIAMS J.A., LAMMING G.E. (2000): Declining fertility in dairy cattle: changes in traditional and endocrine parameters of fertility. Anim Sci 70, 487-501. 
SANDOE P.B., NIELSEN L., CHRISTENSEN L.G., SORENSEN P. (1999): Staying good while playing God-The ethics of breeding farm animals. Anim Welf 8,313-328.

SCHOLZ H., BEYER B., ANACKER G., WÄHNER M. (2010): Relationship between milk yield, fertility and amount of disease of Holstein Friesian dairy cows [in German]. Arch Tierz 53, 283-292.

SØRENSEN A.C., LAWLOR T., RUIZ F. (2007): A survey on fertility in the Holstein populations of the world. Proc. Int Conf on Fertility in dairy cows, Liverpool Hope University, UK (EAAP Satellite Meeting), 17.

STEVENSON J.S. (1999): Can you have good reproduction and high milk yield? Hoard's Dairyman 144-536.

SUN C., MADSEN P., LUND M.S., ZHANG Y., NIELSEN U.S., SU G. (2010): Improvement in genetic evaluation of female fertility in dairy cattle using multiple-trait models including milk production traits. J Anim Sci 88, 871-878.

TEKERLI M., KOCAK S. (2009): Relationships between production and fertility traits in first lactation and life time performances of Holstein cows under subtropical condition. Arch Tierz 52, 364-370.

VACEK M., STADNIK L., ŠTIPKOVA M. (2007): Relationships between the incidence of health disorders and the reproduction traits of Holstein cows in the Czech Republic. Czech J Anim Sci 52, 227-235.

VEERKAMP R.F., KOENEN E.P.C., DE JONG G. (2001): Correlations among body condition score, yield, and fertility in first-parity cows estimated by random regression models. J Dairy Sci 84, 2327-2335.

WINDIG J.J., CALUS M.P.L., VEERKAMP R.F. (2005): Influence of Herd Environment on Health and Fertility and Their Relationship with Milk Production. J Dairy Sci 88, 335-347.

WINDIG J.J., CALUS M.P.L., BEERDA B., VEERKAMP R.F. (2006): Genetic Correlations Between Milk Production and Health and Fertility Depending on Herd Environment. J Dairy Sci 89, 1765-1775. 